\title{
Economic losses associated with Wooden Breast and White Striping in broilers
}

\section{Perdas econômicas associadas as alterações Wooden Breast e White Striping em frangos de corte}

\author{
Marcelo Augusto Zanetti ${ }^{1}$; Denise Cristina Tedesco ${ }^{2}$; Tatiele Schneider ${ }^{2}$; Sabrina \\ Tolotti Fraga Teixeira ${ }^{1}$; Luciane Daroit ${ }^{3}$; Fernando Pilotto ${ }^{4}$; Elci Lotar Dickel ${ }^{4}$; \\ Suelen Priscila Santos ${ }^{1}$; Luciana Ruschel dos Santos ${ }^{4^{*}}$
}

\begin{abstract}
Currently, two defects in poultry breasts termed Wooden Breast (WB) and White Striping (WS) have been reported in slaughterhouses. These defects may be associated with the accelerated growth of the birds, management, density in the aviary, and both weight and age at slaughter. Although the health of the affected birds is not impaired, these myopathies cause carcass condemnation and economic losses to slaughterhouses, since the breasts of these chickens, considered to be prime cuts in the poultry industry, have to be discarded. This paper reports on the economic losses and factors associated with carcass condemnation caused by white striping (WS) and wooden breast (WB) in broilers from a federally inspected slaughterhouse. Twelve flocks, totaling 207,000 slaughtered broilers, were assessed as to weight and age at slaughter, and stocking density and carcass condemnations due to these two myopathies were also evaluated. Economic losses were estimated by the price of poultry breast at the firm level, around U\$ 19,12 per kilo, amounting to daily losses of up to U\$ 70,632.00, given that approximately $0.8 \%$ of the chicken breasts were condemned. Heavier broilers had a larger condemnation rate due to WS and WB, and so did those reared at a smaller density, due probably to their better access to water and feed, which contributed to weight gain and consequent condemnation, resulting in losses that could affect the entire poultry sector.
\end{abstract}

Key words: Myopathies. Meat quality. Slaughterhouses.

\section{Resumo}

Atualmente, dois defeitos em peitos de frango, denominados Peito Madeira (Wooden Breast - WB) e Peito com Estrias Brancas (White Striping-WS) têm sido relatados em abatedouros e podem estar associados ao crescimento acelerado das aves, manejo, densidade no aviário, peso e idade ao abate. Embora não haja comprometimento da saúde das aves afetadas, estas miopatias causam condenações e prejuízos aos abatedouros devido ao não aproveitamento do peito destes frangos, considerado um corte nobre na indústria avícola. Neste trabalho são relatados os prejuízos econômicos e fatores associados às condenações por White Striping (WS) e Wooden Breast (WB) em frangos de corte em um abatedouro sob Inspeção Federal. Foram acompanhados 12 lotes totalizando 207.000 aves abatidas, registrando-

\footnotetext{
${ }^{1}$ M.e em Bioexperimentação, Universidade de Passo Fundo, UPF, Passo Fundo, RS, Brasil. E-mail: zanetticelo@hotmail.com; sabrina.fraga@yahoo.com.br; suelenp@hotmail.com

2 Discentes, Curso de Graduação em Engenharia de Alimentos, UPF, Passo Fundo, RS, Brasil. E-mail: denise.tedesco@hotmail. com; tatiele_schneider_@hotmail.com

3 Prof. Assistente, UPF, Passo Fundo, RS, Brasil. E-mail: ludaroit@upf.br

4 Profs., Programa de Pós-Graduação em Bioexperimentação, UPF, Passo Fundo, RS, Brasil. E-mail: fernandopilotto@upf.br; elcidickel@upf.br; luruschel@upf.br

Author for correspondence
} 
se dados como peso e idade ao abate, densidade nos galpões de criação e condenações por estes dois defeitos. As perdas econômicas foram calculadas a partir do valor do peito de frango na empresa, em torno de $\mathrm{R} \$ 5,90$ o quilograma, gerando prejuízos de até $\mathrm{R} \$ 21.800,00$ ao dia, já que cerca de $0,8 \%$ dos peitos foram desqualificados devido à estas alterações. Aves mais pesadas apresentaram maior condenação por WS e WB, bem como quando criadas em menor densidade, provavelmente devido ao melhor acesso a água e ração, contribuindo para aumento de peso e consequente condenações por estas miopatias, impactando em prejuízos que podem ser extrapolados para todo o setor avícola.

Palavras-chave: Miopatias. Qualidade de carne. Abatedouros.

Changes in poultry meat have become increasingly important and have sustained economic losses within the industry, especially because of White Striping (WS) and Wooden Breast (WB). White striping is characterized by the occurrence of different degrees of white striations on the muscle surface whereas wooden breast (WB) is characterized by pale and hardened areas, which could be accompanied by white striation along the pectoralis major muscle (SIHVO et al., 2014).

Myopathies are visually detected during routine postmortem inspection of carcasses, and Brazilian laws do not establish an official criterion for the acceptability or total rejection of carcasses or of their parts concerning pectoralis major muscle abnormalities. Therefore, poultry breasts with these abnormalities are thrown away, causing losses from condemnation of this breast cut, which is the prime cut of chicken meat and can be commercialized in different forms (whole cuts, bone-in or boneless, skinless, fillets) in Brazil (SARCINELLI et al., 2007).

The probable causes of these abnormalities have been associated with extensive genetic selection for rapid weight gain, which could be inducing abnormal physiological behaviors with muscle tissue damage, triggering dorsal cranial myopathy, deep pectoral myopathy, white striping, and wooden breast. These abnormalities are believed to be associated with accelerated metabolism, rapid growth of muscle fibers, and poor blood supply, leading to metabolic stress, with lower oxygenation and, consequently, smaller removal of residues from the affected muscles (ZHANG et al., 2012).
Factors such as genotype, sex, diet, growth rate, and slaughter weight could also be associated with white striping, and heavier and big-breasted birds are more prone to develop this myopathy (MUDALAL et al., 2014).

Therefore, this paper describes the economic losses caused by white striping and wooden breast and proposes alternatives for the conditional use of these cuts.

The study was conducted in a federally inspected poultry slaughterhouse in the northern region of Rio Grande do Sul State, in southern Brazil, with an average daily slaughter of 260,000 birds/day. The data were collected in 2016 between January 5 and April 26, and included male Cobb broiler flocks aged 45 to 49 days and weighing between 2,160 $\mathrm{g}$ and $3,000 \mathrm{~g}$ from 12 integrated poultry farms, totaling 207,000 birds. The statistical analysis was made according to the following weight categories: less than $2,900 \mathrm{~g} ; 2,901 \mathrm{~g}$ to $2,950 \mathrm{~g} ; 2,951 \mathrm{~g}$ to 3,000 $\mathrm{g}$, and over 3,001 g. The data were collected based on the condemnation by trained federal inspection agents, and the results were analyzed by the chisquare goodness-of-fit test. The training of inspection agents followed the macroscopic classification recommended by Kuttappan et al. (2012): Normal: no visible white striations; moderate WS: striations visible on the muscle, but measuring less than one (1) $\mathrm{mm}$; severe WS: striation measuring more than one (1) $\mathrm{mm}$ and easily observed on the surface of the breast muscle; WB: pale areas expansive with white striation across the breast. However, for the assessment of condemnations, the breasts were grouped into normal (no change) or abnormal (with 
changes - WS and/or WB). Condemnations due to WS and WB were assessed based on the number of slaughtered broilers, rate of condemnations, and price per kilo of chicken breasts ready for commercialization.

Condemnation due to WS and WB amounted to $0.8 \%$ in the assessed flocks. Economic losses were calculated based on the price of poultry breast on a per-kilogram basis in the retail sector in the assessed firm (U\$1,86) and a weight of 1,800 grams, with an average daily slaughter of 260,000 birds/day. The losses would be in the neighborhood of U\$ $68,040.00$, given that the firm slaughters 250,000 broilers/day, and during 22 business days and over the period of 12 months, the losses would reach U\$ $17,962.56$ only at this firm. These data are alarming as they extrapolate economic losses, whose amounts could be invested in improvements at the firm level, by putting a prime cut such as poultry breast to waste and not allowing the commercialization of whole chickens.

There exists no systemic involvement of broilers due to these myopathies (AMARAL, 2014) and these cuts could have conditional use in the manufacture of emulsified products, such as mortadella (RODRIGUES, 2016). In this sense, Nery (2016) cites that carcasses considered cachectic, but without microbiological or chemical involvement, may be utilized for the manufacture of edible products.

Tedesco and Schneider (2016) analyzed meat quality of poultry breasts with WS and WB using parameters such as proximate composition, $\mathrm{pH}$, color, shear force, water holding capacity, and weight loss from cooking, and concluded that such changes do not affect the assessed parameters. Breasts with WS or WB had greater water holding capacity, a desirable feature in industrialized products, suggesting the use of this feedstock for emulsified meat products. Qin et al. (2013) mention that meats with high concentrations of fat and connective tissue can be used in ground products, as sausage formulations containing $15 \%$ of meats with myopathies and nuggets with $30 \%$ did not cause significant changes in product quality. However, poultry breasts with WS and WB are stiffer, possibly due to the higher collagen and connective tissue contents, which may require new technologies for the correction of texture defects (BRAMBILA et al., 2016).

Concerning the factors associated with WB and WS, it was concluded that there was a significant difference $(\alpha=5 \%)$ between body weight and the detected myopathies, revealing that heavier broilers showed a higher prevalence of WS and WB. These findings are in line with Kindlein and Vieira (2015), who mentioned that heavier broilers tend to have more myopathies, such as WS, ranging from moderate to severe.

A correlation was also found between age at slaughter and myopathies, probably due to the weight associated with older broilers, which is consistent with the literature, showing that condemnation increases with age and that there is a significant difference between 30 and 45 days of slaughter regarding the qualitative characteristics of chicken breast (BOIAGIO et al., 2015).

The assessed flocks consisted of male broilers and no significant effects have been described for the relationship between sex and myopathies. Male broilers had a lower prevalence of breasts with mild WS and a higher prevalence of breasts with severe WS, probably due to the larger muscle mass (KUTTAPPAN et al., 2013; TROCINO et al., 2015).

Significant difference $(\alpha=5 \%)$ was found in terms of smaller stocking density and the occurrence of myopathies, which may be attributed to easier access to feed and drinking troughs and consequent weight gain of the assessed flocks. Stocking density is one of the management factors that is mainly related to the optimization of broiler facilities and production, and large densities influence sanitation, growth rate, and carcass yield. For Moreira et al. (2004), population buildup alters social order and 
the atmospheric conditions in the shed, having a negative impact on carcass quality, feather growth, and a higher incidence of carcass injuries.

Moreover, litter moisture increases with stocking density due to the metabolic activity of broilers, heat, larger amount of deject and ammonia levels, and water deposition on the litter, either that which drips from the drinking troughs or that which is excreted by the broilers (OLIVEIRA et al., 2000). Thus, litter moisture largely influences the incidence and severity of injuries to broiler carcasses (OLIVEIRA; CARVALHO, 2002).

\section{Conclusions}

Economic losses from the condemnation of poultry breasts incur major costs in the poultry sector and these losses could be minimized by using this feedstock for the manufacture of edible products. However, further studies are needed to demonstrate that these defects do not entail risks to public health since they are esthetic defects that just devalue these cuts.

\section{References}

AMARAL, P. C. Indicadores de processo inflamatório sistêmico e de lesão muscular de frangos de corte acometidos pela miopatia dorsal cranial. 2014. Dissertação (Mestrado em Bioexperimentação) Universidade de Passo Fundo, Passo Fundo.

BRAMBILA, G. S.; BOWKER, B. C.; ZHUANG, H. Comparison of sensory texture attributes of broiler breast fillets with different degrees of White Striping. Poultry Science, Oxford, v. 95, n. 10, p. 2472-2476, 2016.

BOIAGIO, M. M.; ZUFFO, G. R.; ROZA, L. F.; MIGLIORINI, M. J.; BOTH, F.; DANIELI, B.; BOSCATTO, C.; BARETTA, M. Idade de abate e seu efeito sobre aspectos qualitativos da carne do peito de frangos de corte. In: SEMINÁRIO DE INICIAÇÃO CIENTÍFICA, 25., 2015, Lages. Anais... Lages: UDESC, 2015. p. 63-64. Disponível em: <http://www.udesc.br/ arquivos/idsubmenu/2259/32.pdf $>$. Acesso em: 8 jul. 2016.
KINDLEIN, L.; VIEIRA, L. S. Influência da nutrição em white striping e wooden breast em frangos de corte. In: CONGRESSO DO COLÉGIO BRASILEIRO DE NUTRIÇÃO ANIMAL, 29., 2015, Ribeirão Preto. Anais... Ribeirão Preto: CBNA, 2015. Disponível em: $\quad<$ http://cbna.com.br/arquivos/Palestra-5---LirisKindlein.pdf $>$. Acesso em: 10 jun. 2016.

KUTTAPPAN, V. A.; LEE, Y. S.; ERF, G. F.; MEULLENET, J. F. C.; McKEE, S. R.; OWENS, C. M. Consumer acceptance of visual appearance of broiler breast meat with varying degrees of White stripping. Poultry Science, Oxford, v. 91, n. 5, p. 1240-1247, 2012.

KUTTAPPAN, V. A.; SHIVAPRASAD, H. L.; SHAW, D. P.; VALENTINE, B. A.; HARGIS, B. M.; CLARK, F. D.; McKEE, S. R.; OWENS, C. M. Pathological changes associated with white striping in broiler breast muscles. Poultry Science, Oxford, v. 92, n. 2, p. 331-338, 2013.

MOREIRA, J.; MENDES, A. A.; ROÇA, R. O.; GARCIA, E. A.; NAAS, I. A.; GARCIA, R. G.; PAZ, I. C. L. A. Efeito da densidade populacional sobre desempenho, rendimento de carcaça e qualidade da carne em frangos de corte de diferentes linhagens comerciais. Revista Brasileira de Zootecnia, Viçosa, MG, v. 33, n. 6. p. 1506-1519, 2004.

MUDALAL, S.; BABINI, E.; CAVANI, C.; PETRACCI, M. Quantity and functionality of protein fractions in chicken breast fillets affected by white striping. Poultry Science, Oxford, v. 93, n. 8, p. 2108-2116, 2014.

NERY, L. C. Avaliação microbiológica, físico-química e anatomopatológica de frangos de corte com caquexia. 2016. Dissertação (Mestrado em Bioexperimentação) Universidade de Passo Fundo, Passo Fundo.

RODRIGUES, J. O. Mortadelas elaboradas com peitos de frango com alterações White Striping e Wooden Breast. 2016. Dissertação (Mestrado em Bioexperimentação) Universidade de Passo Fundo, Passo Fundo.

OLIVEIRA, J. E.; SAKOMURA, N. K.; FIGUEIREDO, A. N.; LUCAS JÚNIOR, J. de; SANTOS, T. M. B. Efeito do isolamento térmico de telhado sobre o desempenho de frangos de corte alojados em diferentes densidades. Revista Brasileira de Zootecnia, Viçosa, MG, v. 29, n. 5, p. 1427-1434, 2000.

OLIVEIRA, M. C.; CARVALHO, I. D. Rendimento e lesões em carcaça de frangos de corte criados em diferentes camas e densidades populacionais. Ciências Agrotécnicas, Lavras, v. 26, n. 5, p. 1076-1081, 2002.

QIN, N. The utilization of poultry breast muscle of different quality classes. 2013. Thesis. (Department of Food and Environmental Sciences) - University of Helsinki, Helsinki. 
SARCINELLI, M. F.; VENTURINI, K. S.; SILVA, L. C. Processamento da carne de frango. Vitória: Universidade Federal do Espírito Santo, UFES, 2007. p. 2-7. (Boletim técnico, 2).

SIHVO, H. K.; IMMONEN, K.; PUOLANNE, E. Myodegeneration with fibrosis and regeneration in the pectoralis major muscle of broilers. Veterinary Pathology, Ontario, v. 51, n. 3, p. 619-623, 2014.

TEDESCO, D. C.; SCHNEIDER, T. Atributos de qualidade de carne em peitos de frango com alterações White Striping ou Wooden Breast. 2016. Monografia (Trabalho de Conclusão de Curso em Engenharia de Alimentos) - Universidade de Passo Fundo, Passo Fundo.
TROCINO, A.; PICCIRILLO, A.; BIROLO, M.; RADAELLI, G.; BERTOTTO, D.; FILIOU, E.; PETRACCI, M.; XICCATO, G. Effect of genotype, gender and feed restriction on growth, meat quality and the occurrence of white striping and wooden breast in broiler chickens. Poultry Science, Oxford, v. 94, n. 12, p. 2996-3004, 2015.

ZHANG, L; ZHANG, H. J.; QIAO, X.; YUE, H. Y.; WU, S. G.; YAO, J. H.; QI, G. H. Effect of monochromatic light stimuli during embryogenesis on muscular growth, chemical composition, and meat quality on breast muscle in male broilers. Poultry Science, Champaign, v. 91, n. 4, p. 1026-1031, 2012. 
